(RESEARCH ARTICLE)

\title{
Soil microbial status under different land use systems in Gombe state, Nigeria
}

\author{
James Theophilus 1, ${ }^{*}$, Aliyu El-Hassan ${ }^{1}$, Ishaku Deborah 2, Abubakar Sani Yauta 2, Haruna Isa Mohammed ${ }^{3}$ \\ and Gideon Meshack Madiya ${ }^{1}$
}

${ }^{1}$ Department of Science Laboratory Technology, Gombe State Polytechnic, P.M.B. 0190, Bajoga, Nigeria.

${ }^{2}$ Department of General Studies, Gombe State Polytechnic, P.M.B. 0190, Bajoga, Nigeria.

${ }^{3}$ Department of Microbiology, Nasarawa State University, P.M.B. 1022, Keffi, Nigeria.

Publication history: Received on 23 June 2020; revised on 06 July 2020; accepted on 08 July 2020

Article DOI: https://doi.org/10.30574/wjarr.2020.7.1.0221

\begin{abstract}
Microorganisms are of primary importance for soil quality and natural productivity. Four land use systems viz., Forestry, Horticulture, Agriculture and Pasture at four different locations viz., Bajoga, Gombe, Boderi and Kanawa were identified in determining population of microorganisms in the soil. The samples were collected, numbered and labelled with date and site of collection in an air-tight pre-sterilized polyethene bags before transportation to the laboratory. Serial dilution pour plate technique was used for estimation of total bacterial, fungal, actnomycetes and azotobacter using specific media. The plates were incubated at temperatures specific to particular microbe for $2-3$ days. The colonies that developed on media were counted by electronic colony counter. The microbial counts were expressed as colony forming unit per gram of soil (CFU/g soil). The highest bacterial count (CFU/g) was found in forest land use with the mean value (192.66) and the lowest (41.33) was found in agricultural land use system. The highest total fungal count (CFU/g) was recorded in forest land use with the mean value (77.33) and the lowest (10.33) was found in agricultural land use system. The highest total viable actinomycetes count (CFU/g) was recorded in forest land use with the mean value (62) and the lowest (3) was found in agricultural land use system as compared to other soils in the study area. The perusal of data reveals that for the total azotobacter count (CFU/g), the highest was recorded in forest soils because of the presence of more organic matter with mean value (22.66) as compared with the other land use systems. The lowest was found in agriculture (4.33). Lowest microbial count in agricultural soils may result to poor soil quality and natural productivity which may lead to famine a natural disaster. Planting of cover crops will improve soil structure, enhance soil fertility and sustain or increase soil organic matter and soil biological activity.
\end{abstract}

Keywords: Land use system; Soil; Microbial count; Soil quality; Famine

\section{Introduction}

Soil is a natural body consisting of various horizons of mineral constituents, each with different proportions and has some distinctive features. Besides minerals, soil includes soil organic matter, water and air. The arrangement and extent of these parts significantly impact soil physical properties like structure and porosity. Soil bacteria and fungi play a vital role in different biogeochemical cycles and are in charge of the cycling of natural mixes [1].

Soil is the most abundant ecosystem on Earth, but the vast majority of organisms in soil are microbes, a great many of which have not been described [2]. The total number of organisms and species can vary widely according to soil type, location and depth $[3,4]$. Microorganisms, including bacteria and fungi, affect chemical exchanges between roots and soil and act as a reserve of nutrients in a soil biological hotspot called rhizosphere. Diverse microbial community are supported by soil that plays an important role in ecosystem level processes such as, decomposition of organic matter and nutrient cycling [5].

\footnotetext{
* Corresponding author: James Theophilus
} 
Soil is a fascinating medium for developing microorganisms, as it contains different supplements that the organisms require for their digestion system. Unfortunately, nutrients are not generally promptly accessible [6]. However, it is one of the richest reservoirs of microorganisms, that is, 1 gram of agricultural soil may contain even several billion colony forming units of microorganisms belonging to thousands of different species, and even though microorganisms constitute less than $0.5 \%$ of the soil mass, they have a major impact on soil properties and processes [7].

Land use is characterized by the arrangements, activities and inputs, that people undertake in a certain land cover type to produce change or maintain it [8]. It influences soil aggregation, aggregate stability and overall soil health. The practices affect the distribution and supply of soil nutrients by directly altering soil properties and thereby influencing biological transformations in the rooting zone [9].

Influence of management practices on the size, composition, and function of the soil microbial communities varies greatly depending on their interaction with other abiotic and biotic factors, such as soil type, plant species, and other environmental variables [10]. Alterations in the physical and chemical nature of the soil may lead to change in soil microbial community, number and changes in microbial function [11]. Land use systems such as forestry, pasture, Agriculture e.t.c. ; provide stability and sustainability to the farming system.

The aim of the study is to determine the population of microorganisms in some parts of Gombe State, Nigeria.

\section{Material and methods}

\subsection{Location of investigated area}

The study was carried out in four different locations namely; Bajoga, Gombe, Boderi and Kanawa. Gombe state is situated at latitude $10^{\circ} 17^{\prime} 22.88^{\prime \prime} \mathrm{N}$ and longitude $11^{\circ} 10^{\prime} 2.24^{\prime \prime} \mathrm{E}$. The area encompasses many land uses and among them four dominant land uses are agriculture, forest, pasture and horticulture land use systems.

\subsection{Collection of soil samples}

Four land use systems viz., Forestry, Horticulture, Agriculture and pasture at four different locations (Bajoga, Gombe, Boderi and Kanawa) were identified. Purposive sampling method was followed for collection of the soil samples from a depth of $0-20 \mathrm{~cm}[12]$.

The samples were transferred to an air-tight pre-sterilized polyethylene bags before transportation to the laboratory, numbered and labeled with date and site of collection. When samples could not be processed immediately, they were stored at $4^{\circ} \mathrm{C}$ for no longer than 18 to 24 hours.

\subsection{Estimation of total microbial count}

Serial dilution pour plate technique (by Aneja: delete) [13] was used for estimation of total bacterial, fungal, actnomycetes and azotobacter using specific media that is, nutrient agar media (NA), Martins Rose Bengal media, Actinomycetes agar and Ashbys media respectively. One gram of the rhizosphere soil was placed in $9 \mathrm{ml}$ of sterilized distilled water under aseptic conditions. Serial dilution of $10^{-1}, 10^{-2}, 10^{-3}, 10^{-4}, 10^{-5}, 10^{-6}$ were prepared one ml of aliquot from specific dilution was added over cooled and solidified nutrient media (NA) in petri - plates. The plates were rotated for uniform distribution. The plates were incubated at temperatures specific to particular microbe for 2-3 days. The colonies that developed on media were counted by electronic colony counter. The microbial counts were expressed as colony forming unit per gram of soil (CFU/g soil).

\section{Results}

Table 1 Description of sampling sites under different land use systems of Gombe State

\begin{tabular}{lll}
\hline Land Use System & Location & Site Number \\
\hline Forest & Kanawa & S1, S2, S3 \\
Agriculture & Bajoga & S1, S2, S3 \\
Horticulture & Gombe & S1, S2, S3 \\
Pasture & Boderi & S1, S2, S3 \\
\hline
\end{tabular}


Table 2 Microbial count of soil under different land use systems of Gombe state

\begin{tabular}{lllllll}
\hline LUS & Location & $\begin{array}{l}\text { Site } \\
\text { Number }\end{array}$ & $\begin{array}{l}\text { Total } \\
\text { Bacterial } \\
\text { (CFU/g) }\end{array}$ & $\begin{array}{l}\text { Fungal } \\
\text { (CFU/g) }\end{array}$ & $\begin{array}{l}\text { Actinomycetes } \\
\text { (CFU/g) }\end{array}$ & $\begin{array}{l}\text { Azotobacter } \\
\text { (CFU/g) }\end{array}$ \\
\hline Forest & Kanawa & S1 & 228 & 92 & 77 & 8 \\
& & S2 & 106 & 40 & 52 & 44 \\
Range & & S3 & 244 & 100 & 57 & 16 \\
Mean & & $106-244$ & $40-100$ & $52-77$ & $8-44$ \\
Agriculture & Bajoga & S1 & 62 & 4 & 2 & 22.66 \\
& & S2 & 20 & 19 & 0 & 0 \\
Range & & S3 & 42 & 8 & 7 & 10 \\
Mean & & $20-62$ & $4-19$ & $0-7$ & 3 \\
Horticulture & Gombe & S1 & 137 & 54 & 17 & $0-10$ \\
& & S2 & 42 & 33 & 29 & 4.33 \\
& & S3 & 91 & 21 & 30 & 9 \\
Range & & & $42-137$ & $21-54$ & $17-30$ & 2 \\
Mean & & & 90 & 36 & 25.33 & 17 \\
Pasture & Boderi & S1 & 200 & 76 & 0 & 9.33 \\
& & S2 & 212 & 30 & 44 & 12 \\
& & S3 & 88 & 48 & 28 & 10 \\
Range & & $88-212$ & $30-76$ & $0-44$ & 16 \\
Mean & & 166.66 & 51.33 & 24 & $10-16$ \\
\hline
\end{tabular}

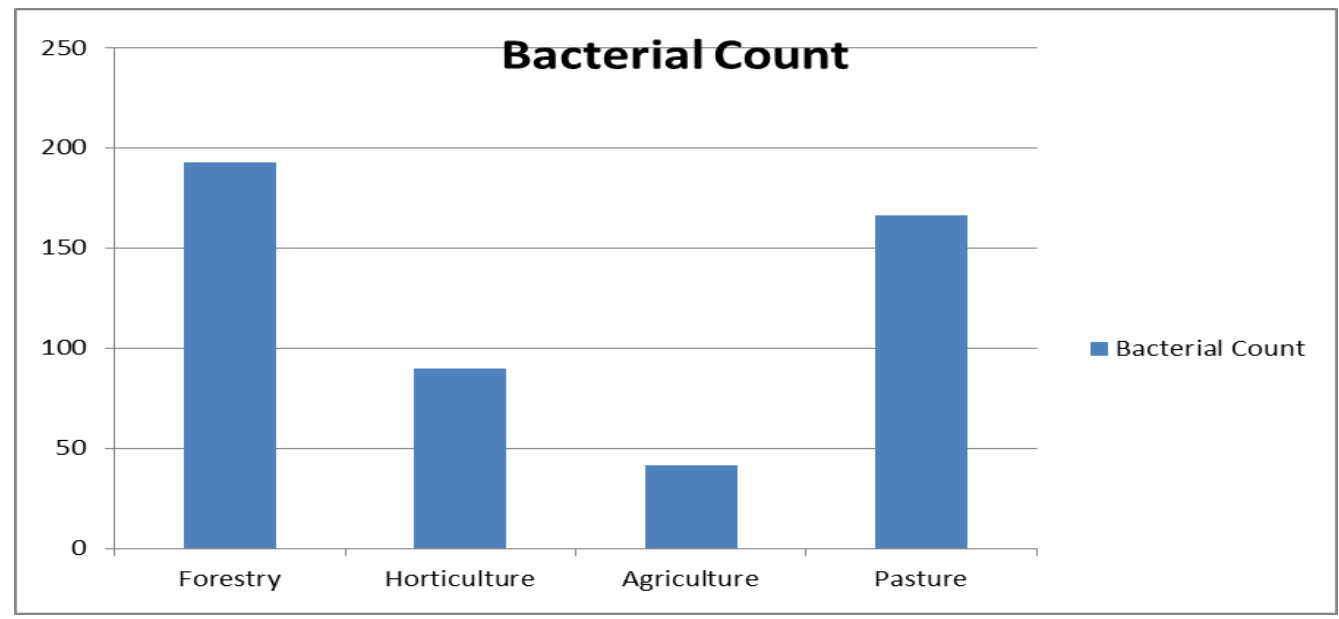

Figure 1 Bacterial count under different land use systems (CFU/g) of Gombe State 


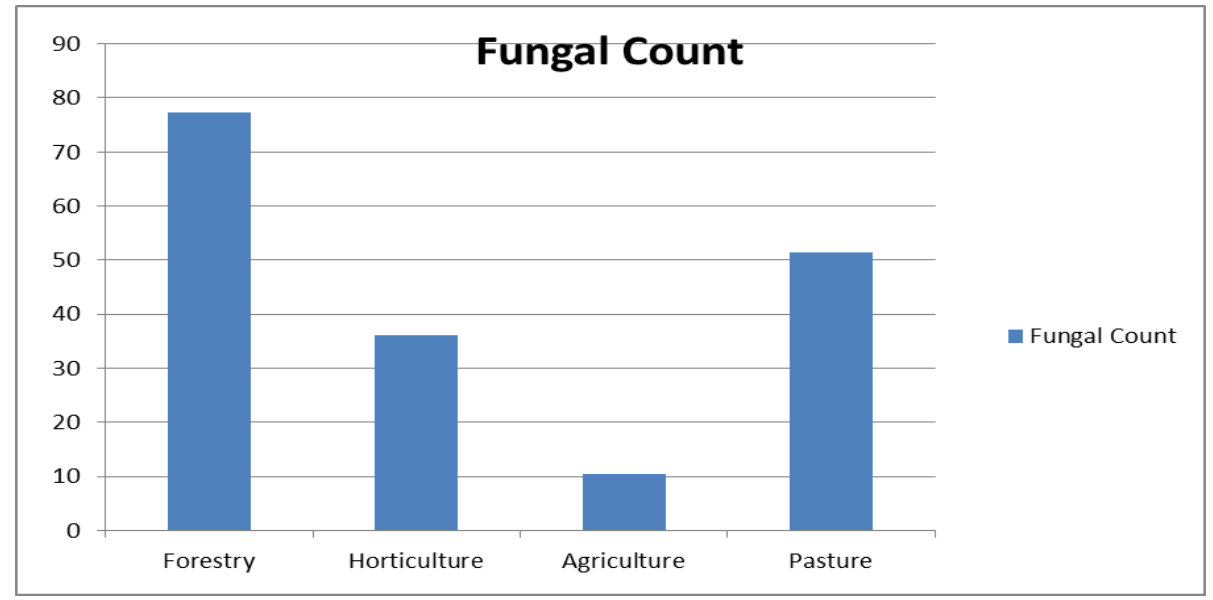

Figure 2 Graph showing fungal count under different land use systems (CFU/g)

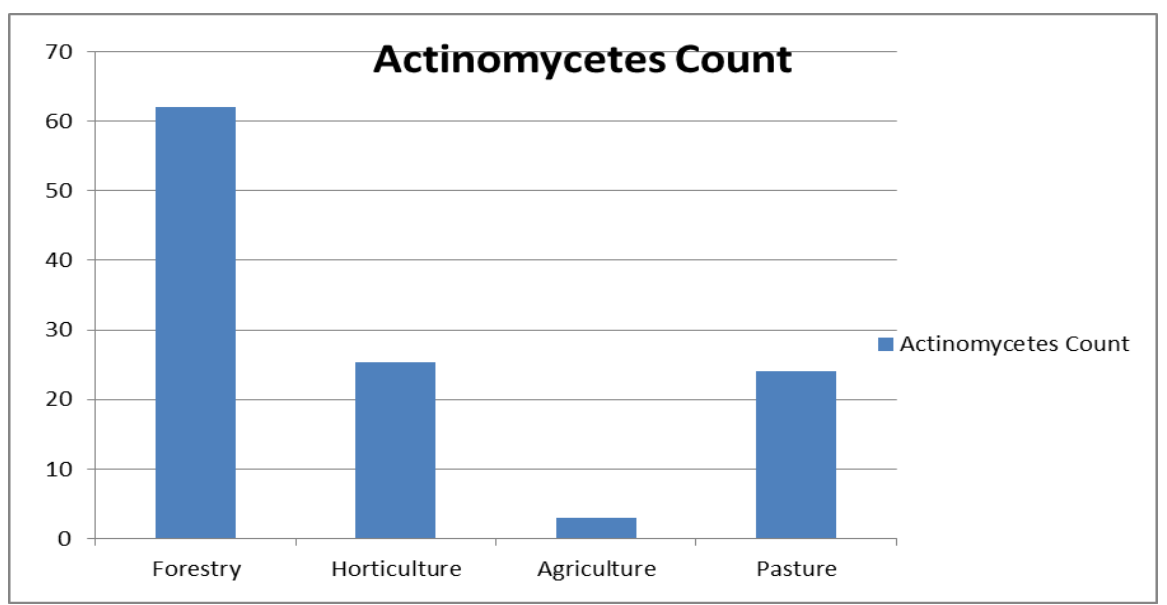

Figure 3 Graph showing actinomycetes count under different land use systems (CFU/g)

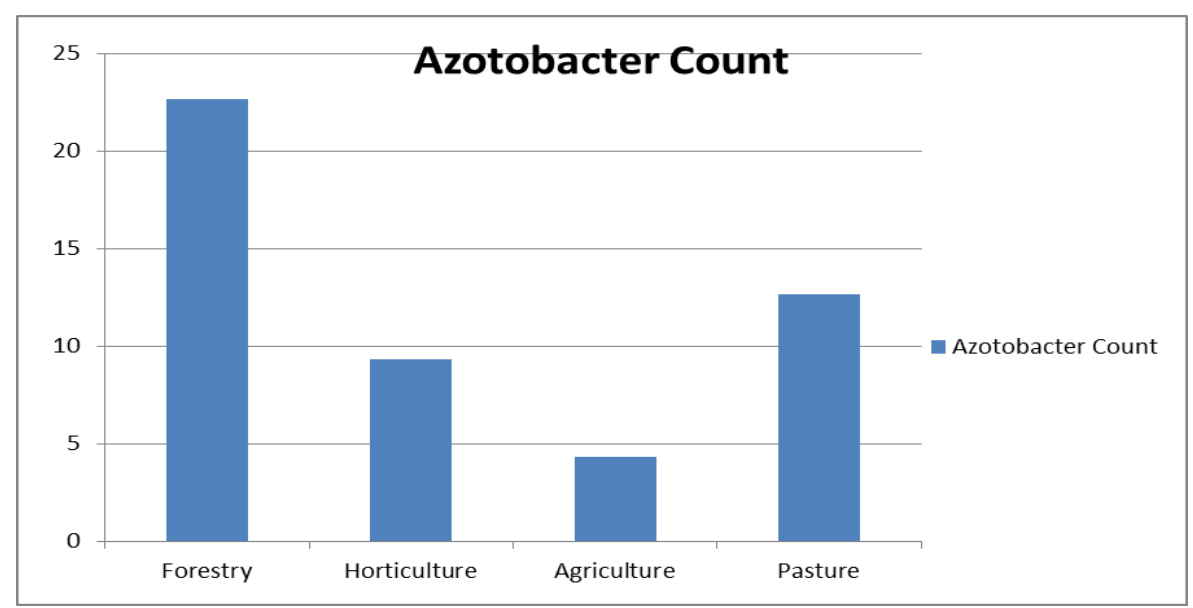

Figure 4 Graph Showing Azotobacter count under different land use systems (CFU/g) 


\section{Discussion}

The data (Table 2) revealed that the results obtained in this study correlates with that ofWaniet al. [14] who observed that forest and pasture showed the highest bacterial count. The highest bacterial count ( $\mathrm{CFU} / \mathrm{g}$ ) was found in forest land use followed by pasture land use system with the mean value (192.66) and (166.66) respectively, horticulture (90) while the lowest (41.33) was found in agricultural land use system.

The number of soil bacteria in the cultivated land was lower than that in the other land use systems; this may result to poor soil quality and natural productivity which may lead to famine. This is probably because of the presence of larger carbon source in the form of organic matter present in the forest and pasture land. The organic matter in soil derives from plants, animals and microorganisms. In forest, for example, leaf litter and woody material falls to the forest floor, when it decays to the point in which it is no longer recognizable, it is called soil organic matter. When the organic matter has broken down into a stable substance that resists further decomposition it is called humus. This carbon source needed for metabolism may have increased the growth and activities of bacteria in soils of these land use systems that is forest and pasture.

The slightly lower $\mathrm{pH}$ of the uncultivated land use type may have also encouraged the growth of bacteria which strive in that level of soil pH. Soil pH has been shown to greatly influence soil microbial community [15].

Similar results that bacterial count was significantly affected by different land use system and conditions, and the highest bacterial count was found in surface soils of forest land use, grassland and lowest in cultivated land was also reported in previous studies $[11,16,17]$.

The mean value of total viable fungi count ( $\mathrm{CFU} / \mathrm{g}$ ) is presented in (Table 2). The highest was recorded in forest land use followed by pasture land use system with the mean value (77.33) and (51.33) respectively, horticulture (36) while the lowest (10.33) was found in agricultural land use system.

Forest soils were generally much higher than the other soils in the study area. The total viable fungal count ranged from $40-100 \mathrm{CFU} / \mathrm{g}$ soil. It might be due to low $\mathrm{pH}$ and higher organic matter in the forest soils. It is also possible that the presence of trees in this land use system may have encouraged the presence of symbiotic relationship that occurs between a fungal symbiont and the roots of various plant species; called ectomycorrhizal fungi which colonize most tree species. Furthermore, the presence of trees in the forestland may have reduced the impact of heavy rainfall and other climatic variables thus, favouring abundant growth of fungi in the forest land [16].

Whereas changes in soil physical properties resulting from tillage operations common in cultivated land may have equally contributed to the reduced number of fungi in the cultivated land. This is because fungi are easily influenced by changes in soil and environmental conditions [18]. Fungal structure (hyphal growth) is greatly affected by conventional agricultural practices.

The results are in unison with other previous findings $[11,16,17]$ who also reported that fungal count was significantly affected by different land use systems however, the highest fungal count of surface and sub-surface soils was found in forest land.

The total viable actinomycetes count (CFU/g) is presented in (Table 2). The highest was recorded in forest land use followed by horticultural land use system with the mean value (62) and (25.33) respectively; pasture (24) while the lowest (3) was found in agricultural land use system as compared to other soils in the study area.

This may be due to higher pore space as well as more organic material in forest and horticulture which is added to the soil through leaf litter which serves as a source of energy for microbial population with good vegetation cover is reason for increased microbial activity. Moreover, the more activity of microorganisms in forest is also due to presence of more plant roots.

The less microbial count in cultivated land was due to low organic matter and use of fertilizers and more tillage practices.

The results corroborate the findings of Okonkwo [19] who also reported that continuous cultivation led to a decrease in the population of bacteria, actinomycetes and algae. Kumaret al. [17] also found that actinomycetes count was significantly affected by different land use system and conditions. However, the highest actinomycetes count of surface and sub-surface soils was found in forest land use. 
The perusal of data (Table 2) reveals that the total azotobacter count (CFU/g) the highest was recorded in forest followed by pasture with mean value (22.66) and (12.66) respectively, horticulture (9.33) while the lowest was found in agriculture (4.33).

The highest microbial count in forests could be attributed to more organic matter in forest soils and its accumulation in soil which acts as food for microorganisms. Higher organic matter levels also result in favourable soil temperature; improve plant root growth and in turn healthy microbial populations. The results agreed with that of other researchers $[11,16,17]$ who also reported highest azotobacter population in agro-forestry and lowest in cultivated lands.

\section{Conclusion}

The present study under four land use systems, viz., Forestry, Horticulture, Agriculture, and Pasture at different locations revealed that the highest microbial count was found in forest soils and lowest in agriculture soils, probably because of presence of larger carbon source in the form of organic matter present in the forest soils as compared to other land use systems.

Agriculture is the major source of food for humans; lowest microbial count in agricultural soils may result to poor soil quality and natural productivity which may lead to famine a natural disaster.

\section{Compliance with ethical standards}

\section{Acknowledgments}

This research did not receive any form of grant from governmental or non-governmental organizations.

\section{Disclosure of conflict of interest}

The authors declare that they have no known competing financial interests or personal relationships that could have appeared to influence the work reported in this paper.

\section{References}

[1] Oladeji SO and Odelade KA. (2016). Screening, isolation and identification of microorganisms from petrochemical contaminated environment. Brazilian Journal of Biological Sciences, 3(5), 201-208.

[2] Gans J, Wolinsky M and Dunbar J. (2005). Computational improvements reveal great bacterial diversity and metal toxicity in soil. Science, 309(5739), $1387-1390$.

[3] Dance A. (2008). Soil ecology: What lies beneath. Nature, 455, 724-725.

[4] Roesch LFW, Fulthorpe RR, Riva A, Casella G, Hadwin AKM, Kent AD, Daroub SH, Camargo FAO, Farmerie WG and Triplett EW. (2007). Pyrosequencing enumerates and contracts soil microbial diversity. The ISME journal, 1(4), $283-290$.

[5] Bundt M, Widmer F, Pesaro M, Zeyer J and Blaser P. (2000). Preferential flow paths: biological 'hot spots' in soils. Science Direct, 33(6), 729-738.

[6] McKinney RE. (2004). Environmental pollution control microbiology. New York: Marcel Dekker, Inc., 234.

[7] Rosello MR and Amann R. (2001). The species concept for prokaryotes. FEMS Microbiology reviews, 25, 39-67.

[8] Abad JR, Khosravi H and Alamdarlou EH. (2014). Assessment the effects of land use changes on soil physicochemical properties in Jafarabad of Golestan province, Iran. Bulletin of Environment, Pharmacology and Life Sciences, 3(3), 296-300.

[9] Nisar M and Lone FA. (2013). Effect of landuse/landcover change on soils of a kashmir himalayan catchmentsindh. International Journal of Research in Earth \& Environmental Sciences, 1(1), 13-27.

[10] Stamenov D, Duric S, Hajnal JT and Seremesic S. (2016). Fertilization and crop rotation effects on the number of different groups of microorganism. Field and Vegetable Crops Research, 53, 96-100. 
[11] Bello HS, Isa T, Isa MA and Akinmuisere K. (2013). Effects of land use on the nature and population of microorganisms in the semi-arid region of north-eastern Nigeria. International journal of environment, 2(1), 224-230.

[12] Maqbool M, Rasool R and Ramzan S. (2017). Soil physico-chemical properties as impacted by different land use systems in district Ganderbal, Jammu and Kashmir: India. International Journal of Chemical Studies, 5(4), 832840.

[13] Aneja RK. (2001). Experiments in microbiology, plant pathology, tissue culture and mushroom production technology. $3^{\text {rd }}$ ed. New age International Publishers, New Delhi, 568.

[14] Wani FS, Akhter F, Mir S, Baba ZA, Maqbool S, Zargar MY and Nabi SU. (2018). Assessment of soil microbial status under different land use systems in North Western zone of Kashmir. International Journal of Current Microbiology and Applied Science, 7(8), 266-279.

[15] Ibekwe AM, Poss JA, Grattan SR, Grieve CM and Suarez D. (2012). Bacterial diversity in cucumber (Cucumis sativus) rhizosphere in response to salinity, soil pH, and boron. Soil Biology and Biochemistry, 42, 567-575.

[16] Asadu CLA, Nwafor IA and Chibuike GU. (2015). Contributions of microorganisms to soil fertility in Adjacent forest, fallow and cultivated land use types in Nsukka, Nigeria. International Journal of Agriculture and Forestry, 5(3), 199-204.

[17] Kumar U, Shahid M, Tripathi R, Mohanty S, Kumar A, Bhattacharyya P, Banwari BG, Priyanka R, Rajagounder P, Bipin J, Nitiprasad S and Arvind N. (2017). Variation of functional diversity of soil microbial community in subhumid tropical rice-rice cropping system under long - term organic and inorganic fertilization. Ecological Indicators, 73,536-543.

[18] Sui X, Feng F, Lou X, Zheng J and Han S. (2012). Relationship between microbial community and soil properties during natural succession of forest land. African Journal of Microbiology Research, 6(42), 7028-7034.

[19] Okonkwo CI. (2010). Effect of burning and cultivation on soil properties and microbial population of four different land use systems in Abakaliki. Research Journal of Agriculture and Biological Sciences, 6(6), 1007-1014.

\section{How to cite this article}

James T, Aliyu E, Ishaku D, Abubakar SY, Mohammed HI and Gideon MM. (2020). Soil microbial status under different land use systems in Gombe state, Nigeria. World Journal of Advanced Research and Reviews, 12(1), 104-110. 